\title{
PLUVIOMETRIC VARIABILITY AND EXTREME PRECIPITATION AND DROUGHTS EVENTS IN THE CENTRAL NORTH MESOREGION OF PARANÁ
}

\author{
CALDANA, Nathan Felipe da Silva - nathancaldana@gmail.com \\ Universidade Estadual de Londrina / UEL \\ RODRIGUES, Leonardo - leonardo.rodrigues@uel.br \\ Universidade Estadual de Londrina / UEL \\ FUJITA, Thais - fujita.thais@gmail.com \\ Universidade de São Paulo / USP \\ EIRAS, Marília Moreira de - eiras.marilia@gmail.com \\ Universidade Tecnologica Federal do Paraná / UTFPR
FERREIRA, Luiz Gustavo Batista - luiz.gustavo@agronomo.eng.br Instituto Agronômico do Paraná / IAPAR
SILVA, Marcelo Augusto de Aguiar e - aguiaresilva@uel.br Universidade Estadual de Londrina / UEL

\author{
Submetido em: $31 / 08 / 2020$ \\ Aceito para publicação em: 11/06/2021 \\ Publicado em: 22/06/2021 \\ DOI: http://dx.doi.org/10.5380/abclima.v28i0.76216
}

\begin{abstract}
Extreme precipitation events cause severe damage in both urban and rural areas. The purpose of this work was to analyze rainfall variability and detect the extremes of precipitation and droughts occurrences and relate them to ENSO phenomena in the Central North Mesoregion of Paraná (MRNCP). We used data from 44 weather stations distributed in the area of the study, from 1976 to 2018. Based on the results, it was identified the precipitation has regional discrepancies, concentrating the highest rainfall in the southern portion. The highest annual precipitation was highly correlated with the periods identified as El Niño, and then in neutrality. There were large occurrences of drought by decent, with emphasis on the winter months, especially in August. High rainfall heights recorded within 24 hours in all regions analyzed, especially in the summer and spring months.
\end{abstract}

KEYWORDS: Vulnerability. Climate risk. climate analysis

\section{VARIABILIDADE PLUVIOMÉTRICA E EVENTOS EXTREMOS DE PRECIPITAÇÃO E SECA NA MESORREGIÃO NORTE CENTRAL DO PARANÁ}

RESUMO: Os eventos extremos de precipitação causam severos danos no espaço urbano e rural. O objetivo deste trabalho foi analisar a variabilidade pluviométrica e detectar os extremos de precipitação e de seca, e relaciona-los com os fenômenos ENOS na Mesorregião Norte Central Paranaense (MRCNP). Utilizou-se dados de 44 estações pluviométricas distribuídas na MRNCP de 1976 a 2018. Com base nos resultados, identificou-se a precipitação possui discrepâncias regionais, concentrando as maiores alturas pluviométricas na porção sul. As maiores precipitações anuais apresentaram grande correlação com os períodos identificados como El Niño, e em seguida, em neutralidade. Houve grande ocorrências de seca por decêndios, com ênfase nos meses de inverno, principalmente em agosto. Grandes alturas pluviométricas registradas no intervalo de 24 horas em todas as regiões analisadas, principalmente nos meses de verão e primavera.

PALAVRAS-CHAVE: vulnerabilidade, risco climático, análise climática 


\section{INTRODUCTION}

The atmosphere is not static. Its characteristics always vary from place to place in different time scales, exhibiting variability from seconds to hours, from days to millennia (AYOADE, 2006). The interactions that occur in the atmosphere itself may be the result of changes and meteorological variations, that can be classified in short, medium and higher variations (SANCHES et al., $2014 ;$ ). The climate is the result of the complex process involving solar energy and it is intensified by the increase in the average global surface temperature in conjunction with extreme precipitation events. The Fifth Assessment Report AR5 showed that these occurrences will become much more frequent throughout the $21^{\text {st }}$ century (IPCC, 2013; CONTI, 2005).

Throughout the planet, several studies exhibited the importance of the precipitation regime for human activities, such as agriculture, with an emphasis on the most different productions and for the zoning and planning of the agricultural calendar (SANTI et al., 2018; DE SOUSA and DE OLIVEIRA, 2018; DE SOUZA et al., 2018; TAYT'SOHN et al., 2018; WIRÉHN et al. , 2018). Thus exhibiting the importance of studies of this genesis for the region.

In Brazil, disasters resulting from extreme events of precipitation episodes occur in more than $80 \%$ of cities, among urban disasters, flooding is responsible for $59 \%$ of records (MARCELINO, 2007; CALDANA et al., 2018). The severe atmospheric instabilities that generate large amounts of rain in a short time, added to the low drainage of urban spaces due the deficiency of infrastructure. Studies that investigate the frequency and intensity of these extreme events, can be useful for decision-making and regional urban planning (BERTILSSON et al., 2018; HUANG et al., 2018; JAMALI, et al., 2018; MUSTAFA, et al., 2018).

For the Paraná State (South of Brazil), agriculture has a key importance for the state economy (IAPAR, 2019). For the segment, understanding the climate variability is necessary, since it actively interferes in the crops to be produced in a given region. The planting time, the management and conduction of crops, the rational use of natural resources are factors dependent on weather conditions, directly infringing on the variability of production (TAYT'SOHN et al., 2018; CALDANA et al., 2019). Studies that identify and predict droughts periods, intense rain, hail, gales and frosts contribute to the optimization of planning, crop management and decision making, aiming at better ways to obtain good results and less environmental damage (CONCEIÇÃO et al. 2018; GELCER et al., 2018; DE MATOS et al., 2018; MEDEIROS et al., 2018; SANTI et al., 2018; DE SOUSA and DE OLIVEIRA, 2018; DE SOUZA et al., 2018).

Thus, the purpose of this study was to analyze the precipitation variability and detect extreme precipitation and droughts events, in addition to identifying the influence of El Niño South Oscillation - ENSO on extreme events in the North Central Paranaense Mesoregion (MRNCP).

\section{MATERIAL AND METHODS}

\subsection{AREA OF STUDY}

The North Central Mesoregion of Paraná (MRNCP) covers an area of $24,532 \mathrm{~km}^{2}$, which corresponds to about $12 \%$ of the state territory. MRNCP 
contemplates totally or partially three Metropolitan Regions: The Metropolitan Region of Londrina (RML) Metropolitan Region of Apucarana and the Metropolitan Region of Maringá (RMM), important areas of urban development (IPARDES, 2019). Its 79 constituent municipalities are home to around 2 million inhabitants (IBGE, 2019), representing $17.7 \%$ of the population of Paraná State. The MRNCP is an apt area for crops productions due the climate and natural soil fertility.

The climatic classification of MRNCP, has a small part of its Cfb area (subtropical, without dry season and cool summer) located in the central and extreme South areas, with higher altitudes, ranging from 800 to $1100 \mathrm{~m}$ (Figure $01)$, and a large part of its area with lower altitudes (300-700 m), to the East in the region with Cfa climate (subtropical, without dry season and hot Summer) according to the Köppen climate classification (NITSCHE et al., 2019).

\subsection{PRECIPITATION DATA}

For the characterization of precipitation in the region, we used data from 44 pluviometric stations from the Instituto Agronômico do Paraná (IAPAR), Instituto Nacional de Meteorologia (INMET), Agencia Nacional de Águas (ANA) and the Instituto Águas Paraná (Figure 01).

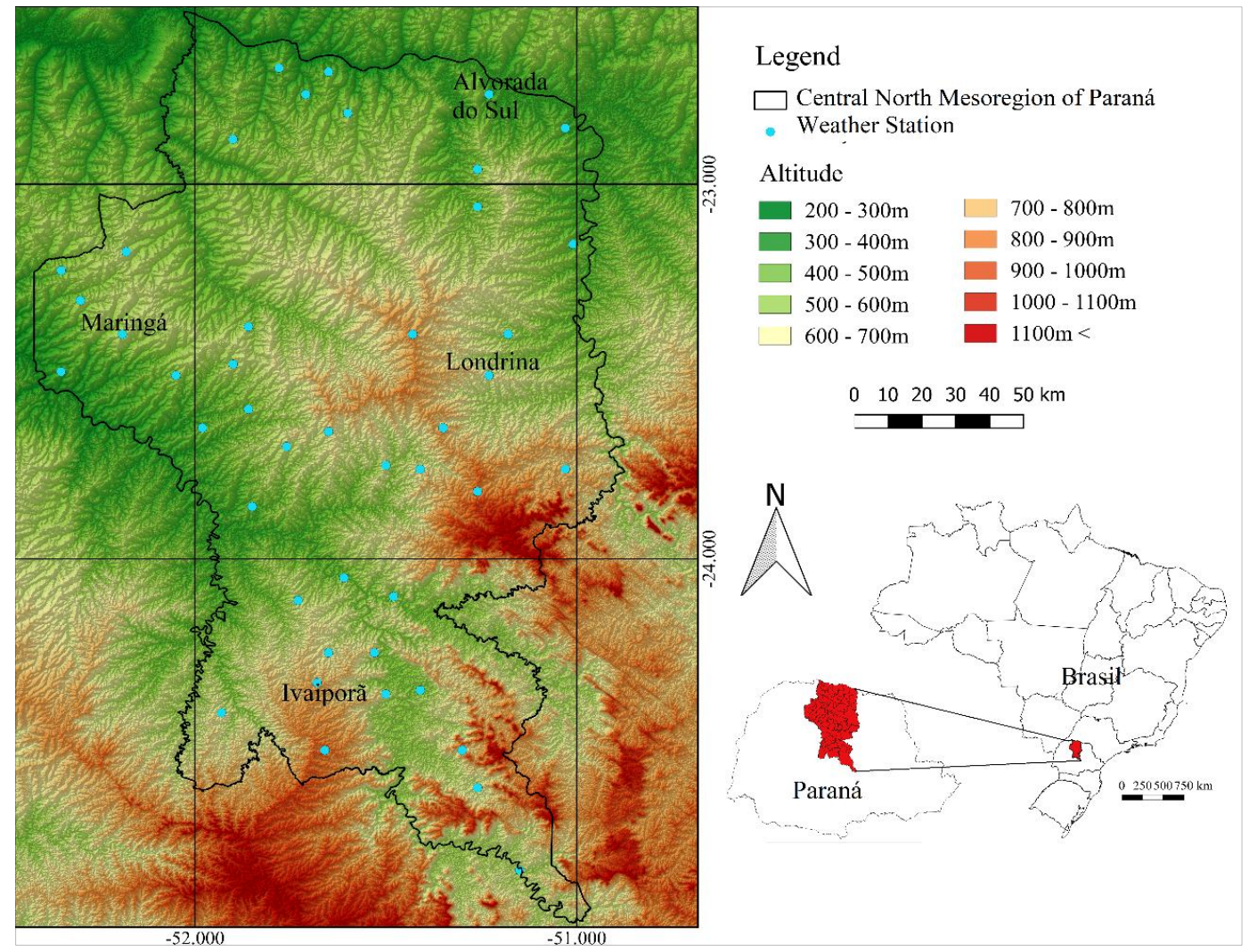

Figure 01 - Stations spatialization and the topography of the North Central Mesoregion of Paraná - MRNCP. Organized by authors (2020).

The spatial distribution of precipitation data was obtained through interpolation using the Inverse distance weighted (IDW) method, with the aid of 
the Qgis Software. The IDW is an interpolator recommended for the spatialization of pluviometric data (MUELLER, 2004). The point data of the pluviometric stations were inserted in the Qgis Software and transformed into a raster file, with the aid of the IDW interpolator. This new file displays a regular surface adjusted to these point data of interest with a pixel of spatial resolution of $1 \mathrm{~km}$ by $1 \mathrm{~km}$. Subsequently, isohyets and their values were inserted for better visualization of areas with similar precipitation.

In addition, to assist in the presentation of the frequency distribution of the data under this study, we used the Box Plot graphics, due it is possible to analyze the measure of their dispersions around the mean by means of standard deviation, the position of its median, its asymmetry and the presence of discrepancies and extremes (LEM et al., 2013; SCHNEIDER and DA SILVA, 2014; COUTO et al., 2016).

For analysis using Box Plot, we used data from four meteorological stations as a parameter, one in each large area of the region and with discrepancies in rainfall (Figure 02). For this purpose, we used the stations from the municipalities, Alto Porã - Ivaiporã (South), Floriano - Maringá (West), São Luiz - Londrina (Center) and Alvorada do Sul (North).

The identification of extreme daily events was carried out using the $99 \%$ percentile of annual precipitation, using the formula: $E e p=\frac{P 99 / 12}{2}$

Eep being the extreme precipitation event;

P99, the percentile $99 \%$ of annual precipitation

Precipitation appears to be characterized as extreme and must have occurred within 24 hours (Table 02). The graphics were created using the Sigma Plot software.

Table 01 - Values of half the average monthly rainfall used as a parameter for identifying extreme events

\begin{tabular}{lllll}
\hline Station & Alto Porã (Ivaiporã) & Alvorada do Sul & $\begin{array}{l}\text { Floriano } \\
\text { (Maringá) }\end{array}$ & $\begin{array}{l}\text { São Luiz } \\
\text { (Londrina) }\end{array}$ \\
\hline Precipitation & $75 \mathrm{~mm}$ & $58 \mathrm{~mm}$ & $62 \mathrm{~mm}$ & $67 \mathrm{~mm}$ \\
\hline
\end{tabular}

Source: Águas Paraná; ANA; IAPAR e INMET (2019). Organized by the authors (2020).

ENSO climate variability data were obtained from the Oceanic Niño Index (ONI) database, published by the Climate Prediction Center of the National Oceanic Atmosphere Administration (NOAA, 2019), in order to compare the occurrence of dry, rainy years and the extreme events with the incidence of $\mathrm{El}$ Niño and La Niña events. ONI is classified by quarterly moving average to determine the Equatorial Pacific Sea Surface Temperature (SST), in the El Niño 3.4 region for each month (TRENBERTH et al., 2019). The comparison of the 
extreme events with the ENSO was carried out by extracting the ten highest pluviometric heights of the series on the annual scales and identifying the phase of influence of the phenomenon in the period.

Table 02 - Years and months of ENSO occurrence (EI Niño in red, La Niña in blue, and Normality in black) between 1976-2017.

\begin{tabular}{|c|c|c|c|c|c|c|c|c|c|c|c|c|}
\hline & $\mathrm{DJF}$ & JFM & FMA & MAM & AMJ & $\mathrm{MJJ}$ & $\mathrm{JJA}$ & JAS & ASO & SON & OND & ND] \\
\hline 1976 & $-1,5$ & $-1,1$ & $-0,7$ & $-0,4$ & $-0,3$ & $-0,1$ & 0,1 & 0,3 & 0,5 & 0,7 & 0,8 & 0,8 \\
\hline 1977 & 0,7 & 0,6 & 0,4 & 0,3 & 0,3 & 0,4 & 0,4 & 0,4 & 0,5 & 0,6 & 0,8 & 0,8 \\
\hline 1978 & 0,7 & 0,4 & 0,1 & $-0,2$ & $-0,3$ & $-0,3$ & $-0,4$ & $-0,4$ & $-0,4$ & $-0,3$ & $-0,1$ & 0 \\
\hline 1979 & 0 & 0,1 & 0,2 & 0,3 & 0,3 & 0,1 & 0,1 & 0,2 & 0,3 & 0,5 & 0,5 & 0,6 \\
\hline 1980 & 0,6 & 0,5 & 0,3 & 0,4 & 0,5 & 0,5 & 0,3 & 0,2 & 0 & 0,1 & 0,1 & 0 \\
\hline 1981 & $-0,2$ & $-0,4$ & $-0,4$ & $-0,3$ & $-0,2$ & $-0,3$ & $-0,3$ & $-0,3$ & $-0,2$ & $-0,1$ & $-0,1$ & 0 \\
\hline 1982 & 0 & 0,1 & 0,2 & 0,5 & 0,6 & 0,7 & 0,8 & 1,0 & 1,5 & 1,9 & 2,1 & 2,1 \\
\hline 1983 & 2,1 & 1,8 & 1,5 & 1,2 & 1,0 & 0,7 & 0,3 & 0 & $-0,3$ & $-0,6$ & $-0,8$ & $-0,8$ \\
\hline 1984 & $-0,5$ & $-0,3$ & $-0,3$ & $-0,4$ & $-0,4$ & $-0,4$ & $-0,3$ & $-0,2$ & $-0,3$ & $-0,6$ & $-0,9$ & $-1,1$ \\
\hline 1985 & $-0,9$ & $-0,7$ & $-0,7$ & $-0,7$ & $-0,7$ & $-0,6$ & $-0,4$ & $-0,4$ & $-0,4$ & $-0,3$ & $-0,2$ & $-0,3$ \\
\hline 1986 & $-0,4$ & $-0,4$ & $-0,3$ & $-0,2$ & $-0,1$ & 0 & 0,2 & 0,4 & 0,7 & 0,9 & 1,0 & 1,1 \\
\hline 1987 & 1,1 & 1,2 & 1,1 & 1,0 & 0,9 & 1,1 & 1,4 & 1,6 & 1,6 & 1,4 & 1,2 & 1,1 \\
\hline 1988 & 0,8 & 0,5 & 0,1 & $-0,3$ & $-0,8$ & $-1,2$ & $-1,2$ & $-1,1$ & $-1,2$ & $-1,4$ & $-1,7$ & $-1,8$ \\
\hline 1989 & $-1,6$ & $-1,4$ & $-1,1$ & $-0,9$ & $-0,6$ & $-0,4$ & $-0,3$ & $-0,3$ & $-0,3$ & $-0,3$ & $-0,2$ & $-0,1$ \\
\hline 1990 & 0,1 & 0,2 & 0,2 & 0,2 & 0,2 & 0,3 & 0,3 & 0,3 & 0,4 & 0,3 & 0,4 & 0,4 \\
\hline 1991 & 0,4 & 0,3 & 0,2 & 0,2 & 0,4 & 0,6 & 0,7 & 0,7 & 0,7 & 0,8 & 1,2 & 1,4 \\
\hline 1992 & 1,6 & 1,5 & 1,4 & 1,2 & 1,0 & 0,8 & 0,5 & 0,2 & 0 & $-0,1$ & $-0,1$ & 0 \\
\hline 1993 & 0,2 & 0,3 & 0,5 & 0,7 & 0,8 & 0,6 & 0,3 & 0,2 & 0,2 & 0,2 & 0,1 & 0,1 \\
\hline 1994 & 0,1 & 0,1 & 0,2 & 0,3 & 0,4 & 0,4 & 0,4 & 0,4 & 0,4 & 0,6 & 0,9 & 1,0 \\
\hline 1995 & 0,9 & 0,7 & 0,5 & 0,3 & 0,2 & 0 & $-0,2$ & $-0,5$ & $-0,7$ & $-0,9$ & $-1,0$ & $-0,9$ \\
\hline 1996 & $-0,9$ & $-0,7$ & $-0,6$ & $-0,4$ & $-0,2$ & $-0,2$ & $-0,2$ & $-0,3$ & $-0,3$ & $-0,4$ & $-0,4$ & $-0,5$ \\
\hline 1997 & $-0,5$ & $-0,4$ & $-0,2$ & 0,1 & 0,6 & 1,0 & 1,4 & 1,7 & 2,0 & 2,2 & 2,3 & 2,3 \\
\hline 1998 & 2,1 & 1,8 & 1,4 & 1,0 & 0,5 & $-0,1$ & $-0,7$ & $-1,0$ & $-1,2$ & $-1,2$ & $-1,3$ & $-1,4$ \\
\hline 1999 & $-1,4$ & $-1,2$ & $-1,0$ & $-0,9$ & $-0,9$ & $-1,0$ & $-1,0$ & $-1,0$ & $-1,1$ & $-1,2$ & $-1,4$ & $-1,6$ \\
\hline 2000 & $-1,6$ & $-1,4$ & $-1,1$ & $-0,9$ & $-0,7$ & $-0,7$ & $-0,6$ & $-0,5$ & $-0,6$ & $-0,7$ & $-0,8$ & $-0,8$ \\
\hline 2001 & $-0,7$ & $-0,5$ & $-0,4$ & $-0,3$ & $-0,2$ & $-0,1$ & $-0,1$ & $-0,1$ & $-0,2$ & $-0,3$ & $-0,4$ & $-0,3$ \\
\hline 2002 & $-0,2$ & 0,0 & 0,1 & 0,2 & 0,4 & 0,6 & 0,8 & 0,8 & 0,9 & 1,1 & 1,2 & 1,1 \\
\hline 2003 & 0,9 & 0,7 & 0,4 & 0 & $-0,2$ & $-0,1$ & 0,1 & 0,2 & 0,2 & 0,3 & 0,3 & 0,3 \\
\hline
\end{tabular}




\begin{tabular}{|c|c|c|c|c|c|c|c|c|c|c|c|c|}
\hline 2004 & 0,3 & 0,3 & 0,2 & 0,1 & 0,2 & 0,3 & 0,5 & 0,6 & 0,7 & 0,7 & 0,6 & 0,7 \\
\hline 2005 & 0,7 & 0,6 & 0,5 & 0,5 & 0,3 & 0,2 & 0 & $-0,1$ & 0 & $-0,2$ & $-0,5$ & $-0,7$ \\
\hline 2006 & $-0,7$ & $-0,6$ & $-0,4$ & $-0,2$ & 0,0 & 0,0 & 0,1 & 0,3 & 0,5 & 0,7 & 0,9 & 0,9 \\
\hline 2007 & 0,7 & 0,4 & 0,1 & $-0,1$ & $-0,2$ & $-0,3$ & $-0,4$ & $-0,6$ & $-0,9$ & $-1,1$ & $-1,3$ & $-1,3$ \\
\hline 2008 & $-1,4$ & $-1,3$ & $-1,1$ & $-0,9$ & $-0,7$ & $-0,5$ & $-0,4$ & $-0,3$ & $-0,3$ & $-0,4$ & $-0,6$ & $-0,7$ \\
\hline 2009 & $-0,7$ & $-0,6$ & $-0,4$ & $-0,1$ & 0,2 & 0,4 & 0,5 & 0,5 & 0,6 & 0,9 & 1,1 & 1,3 \\
\hline 2010 & 1,3 & 1,2 & 0,9 & 0,5 & 0,0 & $-0,4$ & $-0,9$ & $-1,2$ & $-1,4$ & $-1,5$ & $-1,4$ & $-1,4$ \\
\hline 2011 & $-1,3$ & $-1,0$ & $-0,7$ & $-0,5$ & $-0,4$ & $-0,3$ & $-0,3$ & $-0,6$ & $-0,8$ & $-0,9$ & $-1,0$ & $-0,9$ \\
\hline 2012 & $-0,7$ & $-0,5$ & $-0,4$ & $-0,4$ & $-0,3$ & $-0,1$ & 0,1 & 0,3 & 0,3 & 0,3 & 0,1 & $-0,2$ \\
\hline 2013 & $-0,4$ & $-0,4$ & $-0,3$ & $-0,2$ & $-0,2$ & $-0,2$ & $-0,3$ & $-0,3$ & $-0,2$ & $-0,3$ & $-0,3$ & $-0,3$ \\
\hline 2014 & $-0,5$ & $-0,5$ & $-0,4$ & $-0,2$ & $-0,1$ & 0,0 & $-0,1$ & 0,0 & 0,1 & 0,4 & 0,5 & 0,6 \\
\hline 2015 & 0,6 & 0,5 & 0,6 & 0,7 & 0,8 & 1,0 & 1,2 & 1,4 & 1,7 & 2,0 & 2,2 & 2,3 \\
\hline 2016 & 2,5 & 2,2 & 1,7 & 1 & 0,5 & 0 & $-0,3$ & $-0,6$ & $-0,7$ & $-0,7$ & $-0,7$ & $-0,6$ \\
\hline 2017 & $-0,3$ & $-0,1$ & 0,1 & 0,3 & 0,4 & 0,4 & 0,2 & $-0,1$ & $-0,4$ & $-0,7$ & $-0,9$ & -1 \\
\hline 2018 & $-0,9$ & $-0,8$ & $-0,6$ & $-0,4$ & $-0,1$ & 0,1 & 0,1 & 0,2 & 0,4 & 0,7 & 0,8 & 0,9 \\
\hline
\end{tabular}

Source: NOAA/CPC. Organized by the authors (2020).

\section{RESULTS AND DISCUSSION}

\subsection{PLUVIOMETRIC VARIABILITY}

We verified that the rainfall at MRNCP had regional discrepancies (Figure 02). From the average annual precipitation accumulated for the period, it is observed that the North region had the pluviometric heights ranging from 1400 to $1550 \mathrm{~mm}$. The West region presented heights from 1530 to $1650 \mathrm{~mm}$, while the Center-East ranged from 1620 to $1725 \mathrm{~mm}$. The South region was the one that registered the highest average annual pluviometric heights varying from 1600 to $1785 \mathrm{~mm}$.

From the perspective of the topography from the region (Figure 01), it can be observed the precipitation influence on the of the region, since the Central, East and South areas have the highest altitudes in the mesoregion, ranging from 500 to over $1100 \mathrm{~m}$ and exhibits the highest precipitation rates. Meanwhile, the North and West portions, with the lowest rainfall, presented altitudes of 200 to $600 \mathrm{~m}$, and the lowest levels of accumulated precipitation without exceeding $1600 \mathrm{~mm}$. 


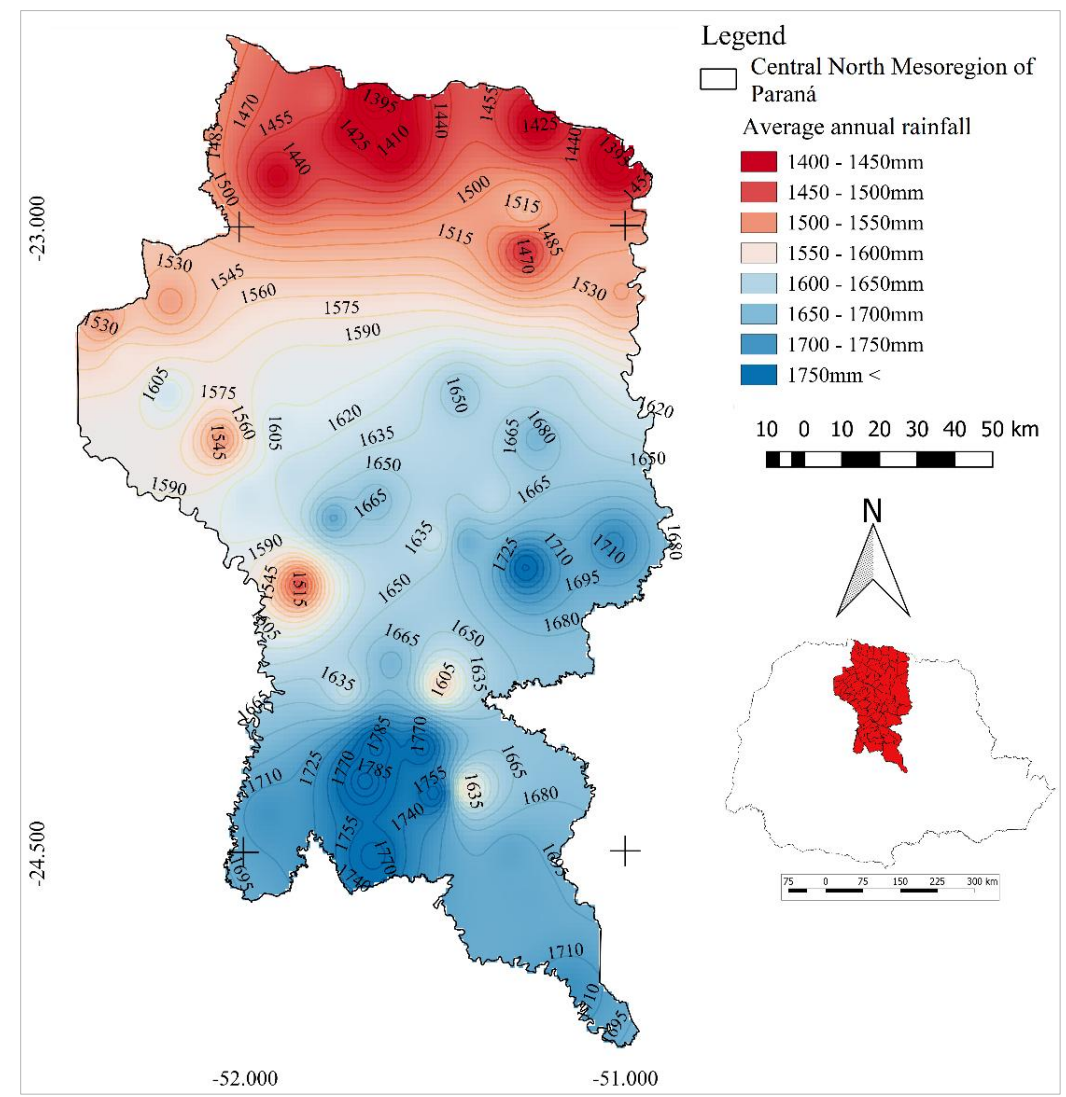

Figure 02 - Average annual rainfall in the North Central Mesoregion of Paraná. Source: Águas Paraná; ANA; IAPAR e INMET (2019). Organized by authors(2020).

To better identify the distribution of annual rainfall, we used the Box Plot plot of rainfall in the mesoregion (Figure 03). As in the interpolation map (figure 02), it is possible to notice a significant discrepancy between rainfall values along the Mesoregion.

At the Alvorada do Sul station, located in the Far North of the region, the lowest annual rainfall was observed, with no discrepant events. The minimum and maximum values found were, respectively: $955 \mathrm{~mm}$ in the year 1981, observed during the normal period of the SST (Table 01) and 2,080 $\mathrm{mm}$ in the year 2000 registered in the El Niño period, with half of the accumulated precipitation events presented in $1412 \mathrm{~mm}$.

For Maringá, located in the western region of the MRNCP, a discrepant value of $2,078 \mathrm{~mm}$ was recorded in 2015 , identified as the El Niño period. The median of this station was $1,480 \mathrm{~mm}$. While the variation between the maximum and minimum values was 2,000 mm, recorded in 1983 under the influence of El Niño at $1024 \mathrm{~mm}$ in 2011, the year of transition between La Niña and normality.

For Londrina, the median annual precipitation was $1,660 \mathrm{~mm}$. A discrepant value of $2,689 \mathrm{~mm}$ was observed in 2015, as already mentioned, under the influence of El Niño. The variation between the maximum and minimum values was, respectively, 2,331 $\mathrm{mm}$ recorded in 2009, under the 
influence of El Niño at 1,153 mm, in 1985, the observed period of the La Niña phenomenon.

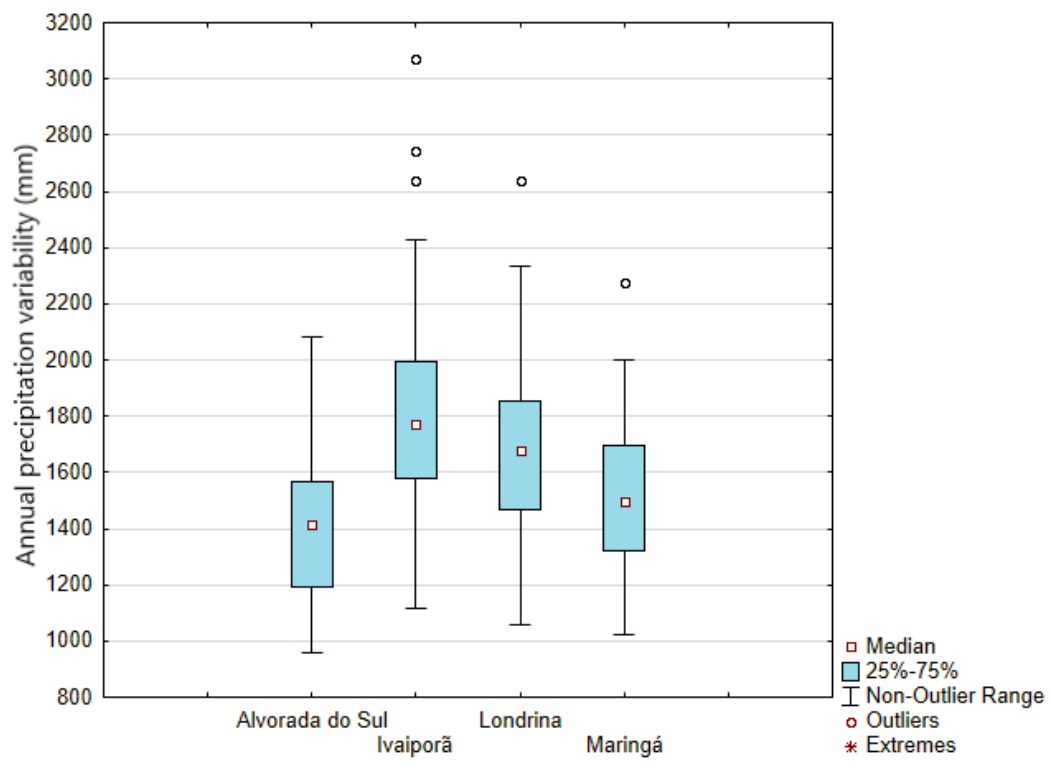

Figure 03 - MRNCP annual precipitation variability (1976 - 2018). Source: Águas Paraná; ANA; IAPAR e INMET (2019). Authors (2020).

For Ivaiporã, three discrepancies were observed, with 3,040, 2,715 and 2,630 $\mathrm{mm}$ in the years 2015, 1983 and 2009, respectively, all of them under the influence of El Niño. The interval between the quartiles was from 1,590 to 1,996 $\mathrm{mm}$. The median of this station was the highest among those analyzed, with $1,785 \mathrm{~mm}$. The lowest annual rainfall in this season was $1,123 \mathrm{~mm}$ in 1985 , the year of La Niña's influence.

Although the discrepancy is large between the regions, it is noted that the size of the rectangle, represented by the difference between the third and the first quartiles, is practically the same, varying between $403 \mathrm{~mm}$ to $340 \mathrm{~mm}$ for the Ivaiporã and Londrina stations, respectively. This measure guarantees a more robust interpretation of the variability of precipitation over the investigated period. As well as the vertical lines that also indicates a symmetrical amplitude, with the exception of Alvorada do Sul, that the lower line represents half of the upper line, indicating more cases of rainy years than droughts periods for this station.

As for monthly precipitation, however for the 44 stations used in the Mesoregion, there were also large variations between locations and discrepancies between monthly values (Figure 04). In the red curve, monthly average between the seasons for the years investigated, it is identified that between the driest $(94 \mathrm{~mm})$ and the rainiest $(210 \mathrm{~mm})$ month the discrepancy is more than $100 \mathrm{~mm}$. 


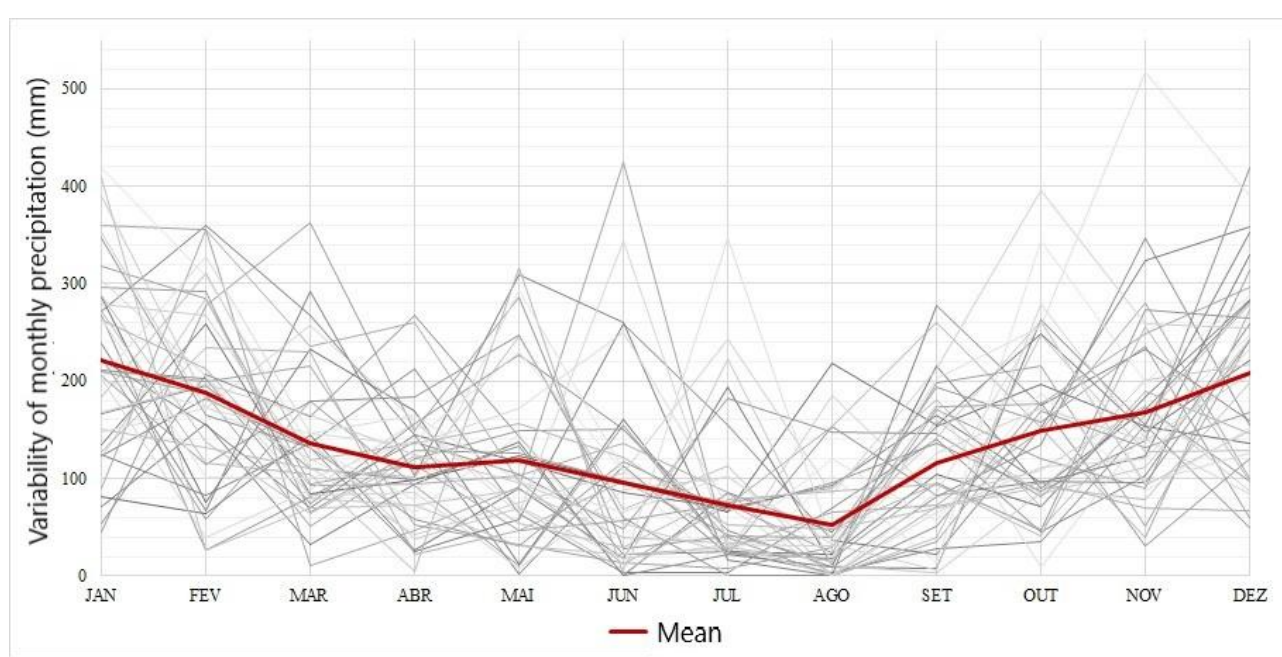

Figure 04 - Variability of monthly precipitation in the MRNCP (1976-2018). Source: Águas Paraná; ANA; IAPAR e INMET (2019). Authors (2020).

Thus demonstrating to be a rainy region more with asymmetric distribution. From a monthly perspective, one can also observe large variations between rainfall, as in June the range of precipitation ranging from 0 to $420 \mathrm{~mm}$ and in November from 38 to $510 \mathrm{~mm}$, among all stations verified for this study.

We used Box Plot in order to improve the visualization of monthly precipitation, (Figure 05). The stations exhibited an approximate distribution to the average annual variability. The Spring and Summer months are rainier, while the Fall and Winter months are drier, with a slight increase in intensity for the months of May. From January to August, the transition from the rainy season to the driest season in the region is noticeable, with a decrease in precipitation, as can be seen by the medians. The only exception is in the Ivaiporã station, in which the month of May is rainier than in the other Fall months.

At the Alvorada do Sul station, an extreme precipitation event occurred in January, reaching a value of $602 \mathrm{~mm}$, in 2005, under the influence of El Niño. The discrepant events for the other months of this point, with the exception of the month of October, were recurrent. Extreme values of February (2001-La Niña), June (2012-Normality) and December (1982-El Niño) stand out, which were close in intensity even though they are from completely different stations. It is only in this station that the $25 \%$ quartile remains at zero for the month of August, indicating once again that, between the seasons, Alvorada do Sul is the one with the lowest precipitation intensities. The months from April to August had medians less than $100 \mathrm{~mm}$. 

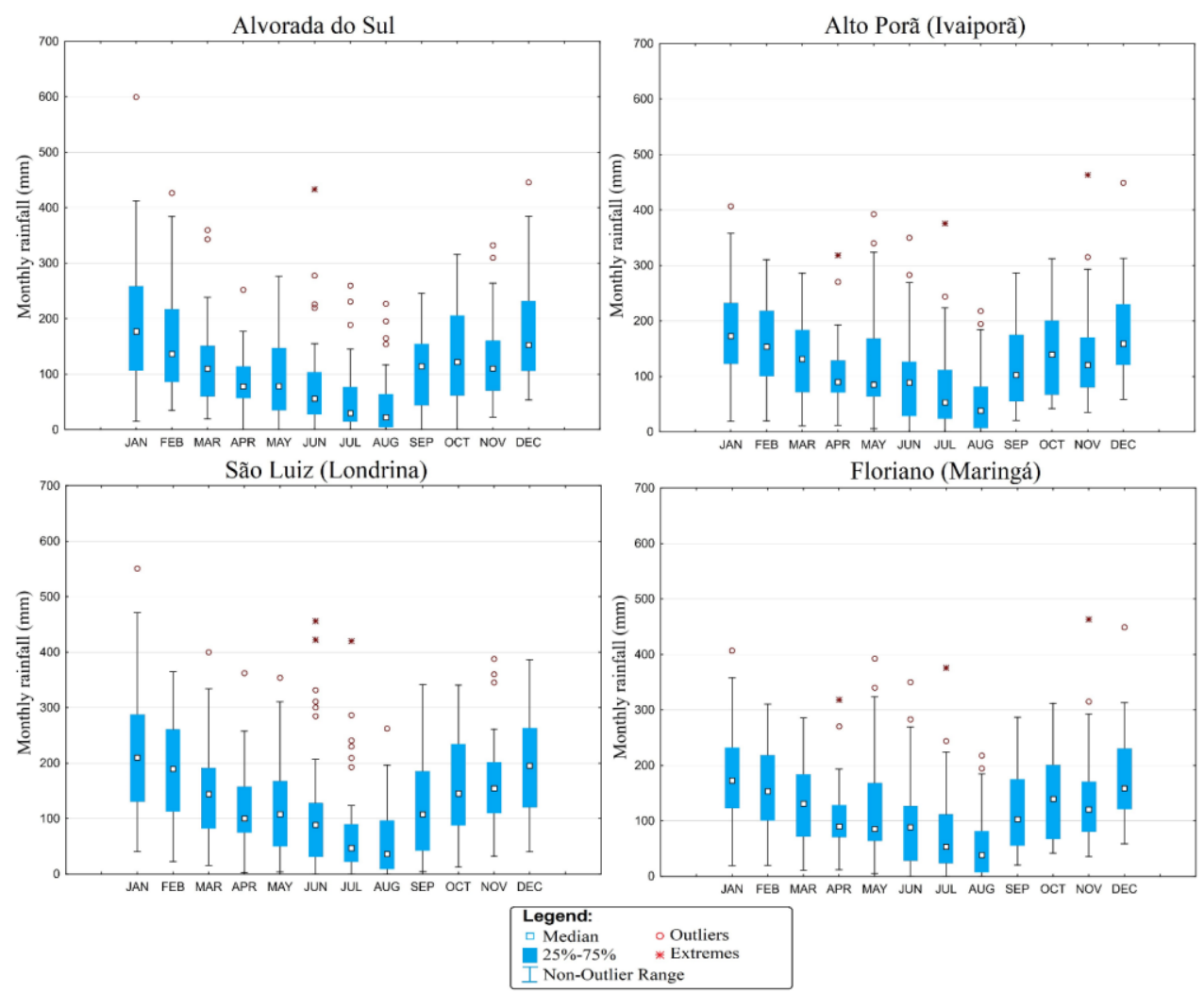

Figure 05 - MRNCP monthly rainfall variability (1976-2018). Source: Águas Paraná; ANA; IAPAR e INMET (2019). Authors (2020).

As for the minimum extremes, there were seven months without precipitation in the series analyzed between April and October. Most of the Box Plots had a non-asymmetric distribution.

For the Ivaiporã station, there were two extreme values in the months of June 1982-Normality $(547 \mathrm{~mm})$ and July 2013-Normaldiade (585 mm). Another fourteen outliers were observed during the historical series, not being observed only in the months of February and May. However, it was in the month of May that there was great variability of precipitation, between 4 and $389 \mathrm{~mm}$. The months of April and August were the only ones that did not register precipitation in any of the years analyzed.

In ENSO neutral conditions, as noted, there were several records of extreme events. During these periods of anomaly, high rainfall occurs in the southern region of Brazil, as there is a reduction in atmospheric blocks in the subtropical range, while in the tropical range of South America the air that ascends to the west (low atmospheric pressure) tends to descend over cold waters at east (high atmospheric pressure). As a result, there is an absence of clouds and precipitation in this region (RAO and HADA, 1997; FONTANA and BERLATO, 1997; PODESTA et al., 2002; BERLATO, 2005; BERLATO and FONTANA, 2011; ANDERSON et al., 2017). Factor that justifies high rainfall in all analyzes for the period of neutrality in the region.

For the Londrina station, seventeen discrepancies were observed, and those between the months of June and July, both presented six extreme values. 
In addition, the months of April, May, June, July and August recorded the monthly interval with $0 \mathrm{~mm}$. The month of January showed the greatest variation between monthly rainfall, ranging from 30 to $565 \mathrm{~mm}$. Most of the Box Plots also had a non-asymmetric distribution.

At the Maringá station, there were fifteen discrepancies, with the months of April, May, July and November standing out. There were two episodes with precipitation of $0 \mathrm{~mm}$ in the interval of 30 days, in the months of July and August. As in Alvorada do Sul, the medians from April to August were less than $100 \mathrm{~mm}$.

\subsection{EXTREME CLIMATIC EVENTS OF PRECIPITATIONS AND DROUGHTS PERIODS}

The ten highest annual pluviometric heights were classified to identify extreme precipitation events, and thus compare with the corresponding SST period (Figure 06). It was observed that the majority of high annual rainfall occurs in periods of El Niño, and only four of the 40 rainfalls analyzed were in the period of La Niña.
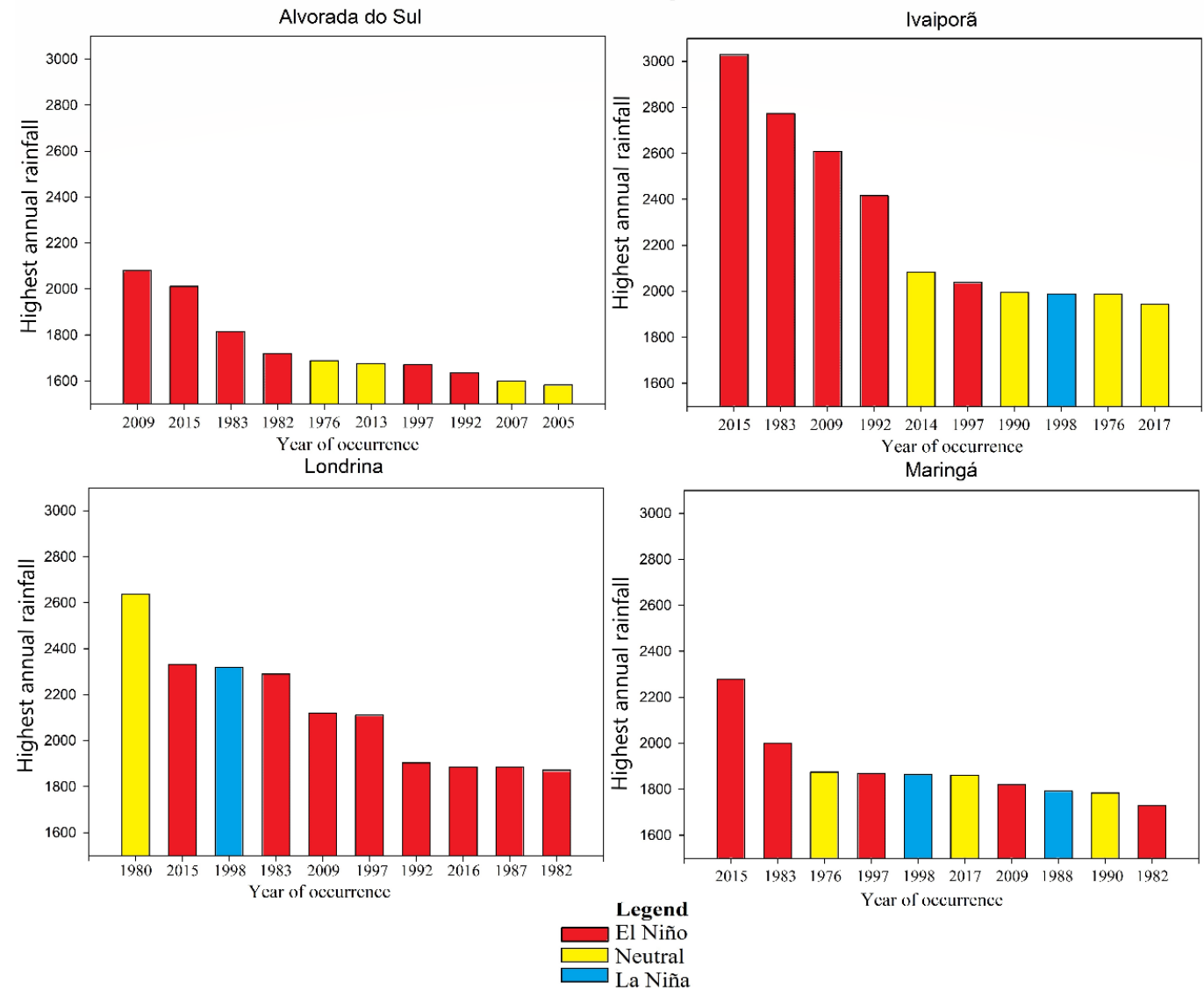

Figure 06 - Highest annual rainfall in Mesoregion Norte Central Paranaense and comparison with El Niño-Oscilação Sul. Source: Águas Paraná; ANA; IAPAR e INMET (2019); NOAA/CPC (2019). Authors (2020). 
In Alvorada do Sul and Ivaiporã the four highest annual pluviometric heights occurred during the El Niño anomaly period. The Ivaiporã station was the most influential in the normal period, with four of the ten highest annual rainfall, while Londrina, even with the highest rainfall in the normal period, was the most influential in El Niño, with eight of the ten analyzed rainfall.

It is should be noted we verified 12 events in neutrality condition also higher classified as El Nino. In some years, in ENSO conditions can occur higher periods of rainfall in the Southern Brazil, due there a reduction of atmospheric block in the subtropical area, while for the tropical region of Southern America, the air ascend to West (low atmospheric pressure) shows tendency to down under the cold waters in Eastern (Higher atmospheric pressure). As a consequence, we verified non presence of precipitation clouds in this area (Rao, Hada, 1990; Berlato et al., 2005; Anderson et al., 2018). All this justified the higher prepositions verified in some analysis for the neutrality period in region of this study.

From the perspective of decendial precipitation, (Figure 07), in which ten consecutive days are considered, counting 36 ten-year periods. Interpretation by this bias favors agricultural practices that, in their planning, consider that 10 days without rain or in excess can be decisive in production variability (FIETZ et al. 1998; CARAMORI, 2008; DALLACORT et al. 2011). In this sense, it was observed that all ten days had at least one occurrence without precipitation and numerous incidences of extreme or discrepant precipitations.

Between the stations, it is observed that the minimums, referring to the minimum values up to the $25 \%$ quartile, are higher in the humid periods (summer and spring) while during the dry periods (autumn and winter) they receive the value zero and create box smaller plots. The ten days of May showed greater variation during the drier period with several discrepancies, in addition to greater variation between quartiles.

At the Alvorada do Sul station, the greatest discrepancy between the maximum and minimum values was observed, which were not considered to be discrepancies. In the period 2/02, a difference of 0 to $240 \mathrm{~mm}$ was observed, the largest detected among the analyzed stations. At the Ivaiporã station, on the other hand, there was the greatest rainfall in one decade among the analyzed stations, $359 \mathrm{~mm}$ in the 1/12 decade. Altogether there were 62 extreme descending events, 22 in Alvorada do Sul, 17 in Londrina, 12 in Maringá and 11 in Ivaiporã. 


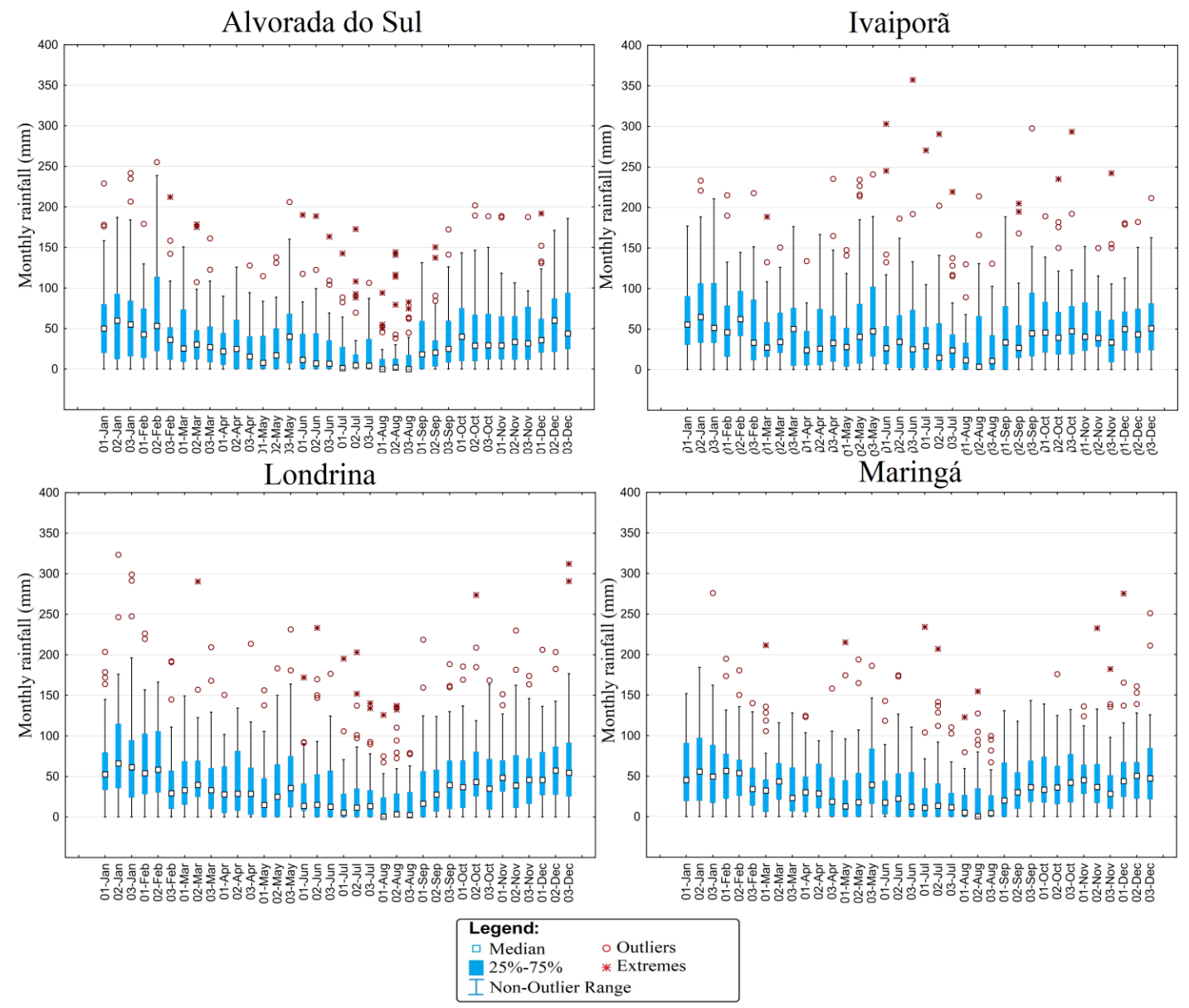

Figure 07 - Variability of the MRNCP's decade-long precipitation (1976-2018). Source: Águas Paraná; ANA; IAPAR e INMET (2019). Authors (2020).

For the detection and probability of occurrences of droughts per decade, the graph in Figure 08 was used. The stations exhibited approximate variability according to the previous analyzes. Thus, the probability of drought in Ivaiporã is lower, in practically all scenarios than in Alvorada do Sul. There is a large discrepancy between the behavior of the stations, even if they are only $169 \mathrm{~km}$ apart, since the station and Ivaiporã, portrays a more homogeneous behavior, while Alvorada, from several perspectives, presented quite different behavior.

The Winter months showed a high probability of drought occurrences in all stations. At the Alvorada do Sul station, every ten days of this station presented at least a $30 \%$ chance, reaching a $76 \%$ risk. For agriculture from 10 to 20 days of rain at the time of sowing, flowering or filling of grains, they can be decisive for the success of the harvest, even if it is a rainy region, its distribution during the year is asymmetrical, and therefore, attention to the planning of the agricultural calendar and the phenological scale of the species cultivated for this period in the region.

The risk gradually declines from the second ten-day period of September. From this period on, the soybean sowing period in the state begins. The risk decreases even more in October, the most recommended period for planting and with lower risk throughout the state, as identified by Ferreira et al. (2020). 
While in August, in addition to the high risk of dry spells, there is still the occurrence of extreme cold (OLIVEIRA and BORROZZINO, 2018), it is normally the harvest period, with no major losses due to dry spells in this period.

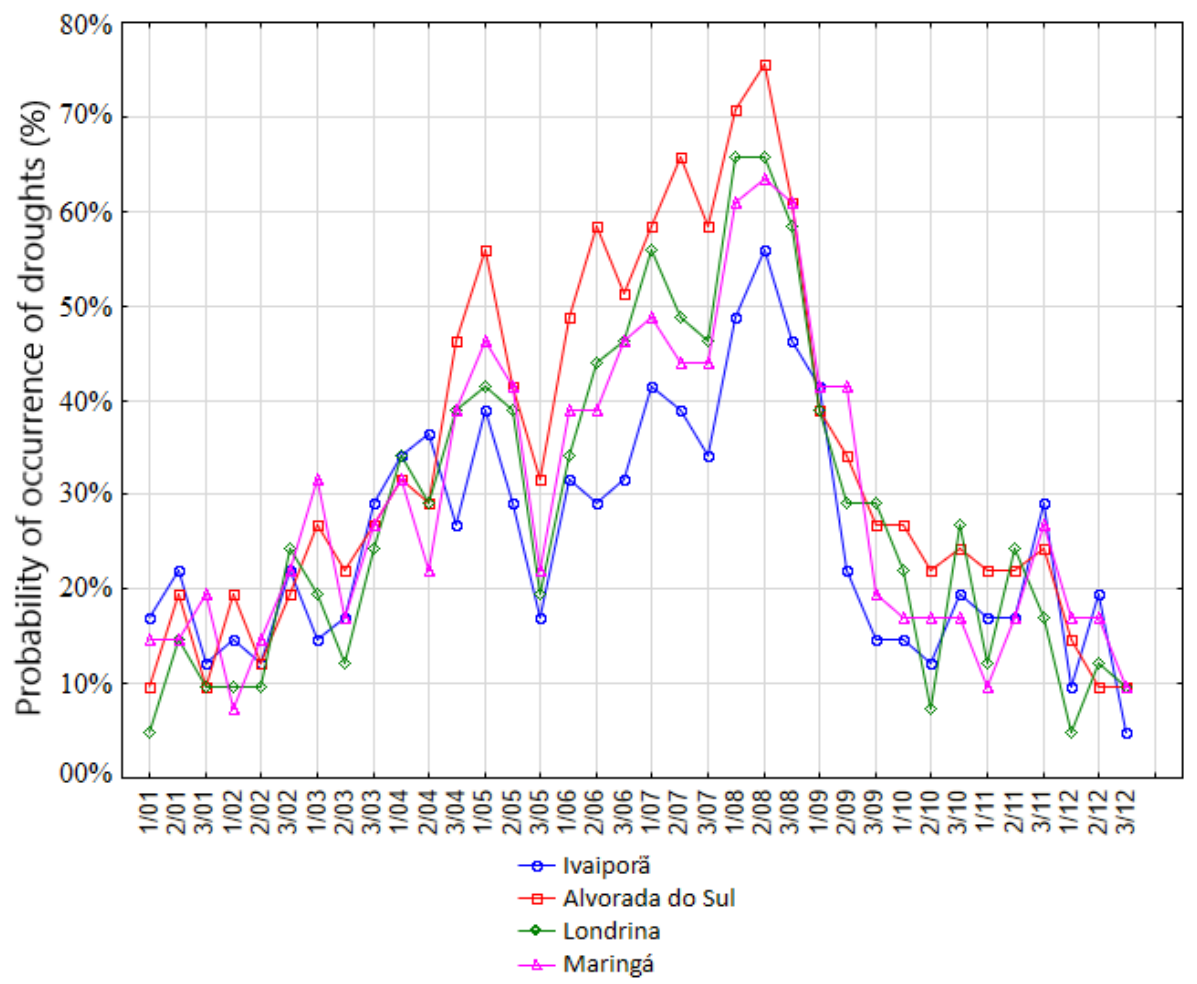

Figure 08 - Probability of occurrence of droughts for 10 years at MRNCP. Source: Águas Paraná; ANA; IAPAR e INMET (2019). Authors (2020).

And even in Summer crops, attention should be paid. In most decades, the risk remains at less than $20 \%$, but it still exists. In the spring, the risk of drought varies from 10 to $40 \%$. The fall showed a large discrepancy, reaching $60 \%$ risk in May.

In order to detect the daily extremes that most influence the urban space, causing floods, floods, runoff and floods (MARCELINO, 2007), the graph in Figure 09 was based on different monthly distributions between the seasons, but present in most months.

At the Alvorada do Sul station, extreme daily events were concentrated mainly in the months of October, February and March. In spring and summer, in the Paraná State, Convective Systems and CCM formations predominate (DAFIS et al., 2017; TREFAULT et al., 2018; CALDANA et al., 2018; CALDANA et al., 2019a; CALDANA et al., 2019b; CALDANA and MARTELÓCIO, 2019). Even though CCMs take place on a large regional scale, rainfall distribution may differ between areas of the state (BORSATO et al., 2019).

At the Ivaiporã station, the far South of the Mesoregion, May was the month with the most occurrences. In Paraná, in the Fall and winter seasons, the Convective Systems and CCM still occur, however, the Cold Front passages cause great instabilities in these stations, which can lead to the formation of strong storms at the moment of the meeting of the air masses. They can still 
have a longer and less intense duration, as in the Stationary Fronts with the precipitation lasting for several days (PUNGE and KUNZ, 2016; BEREZUK, 2017; CALDANA and MARTELÓCIO, 2019).

It is also worth mentioning Maringá, which had the most regular distribution, being able to present large volumes of daily rain during all months of the year, except for August (the driest month in the region).
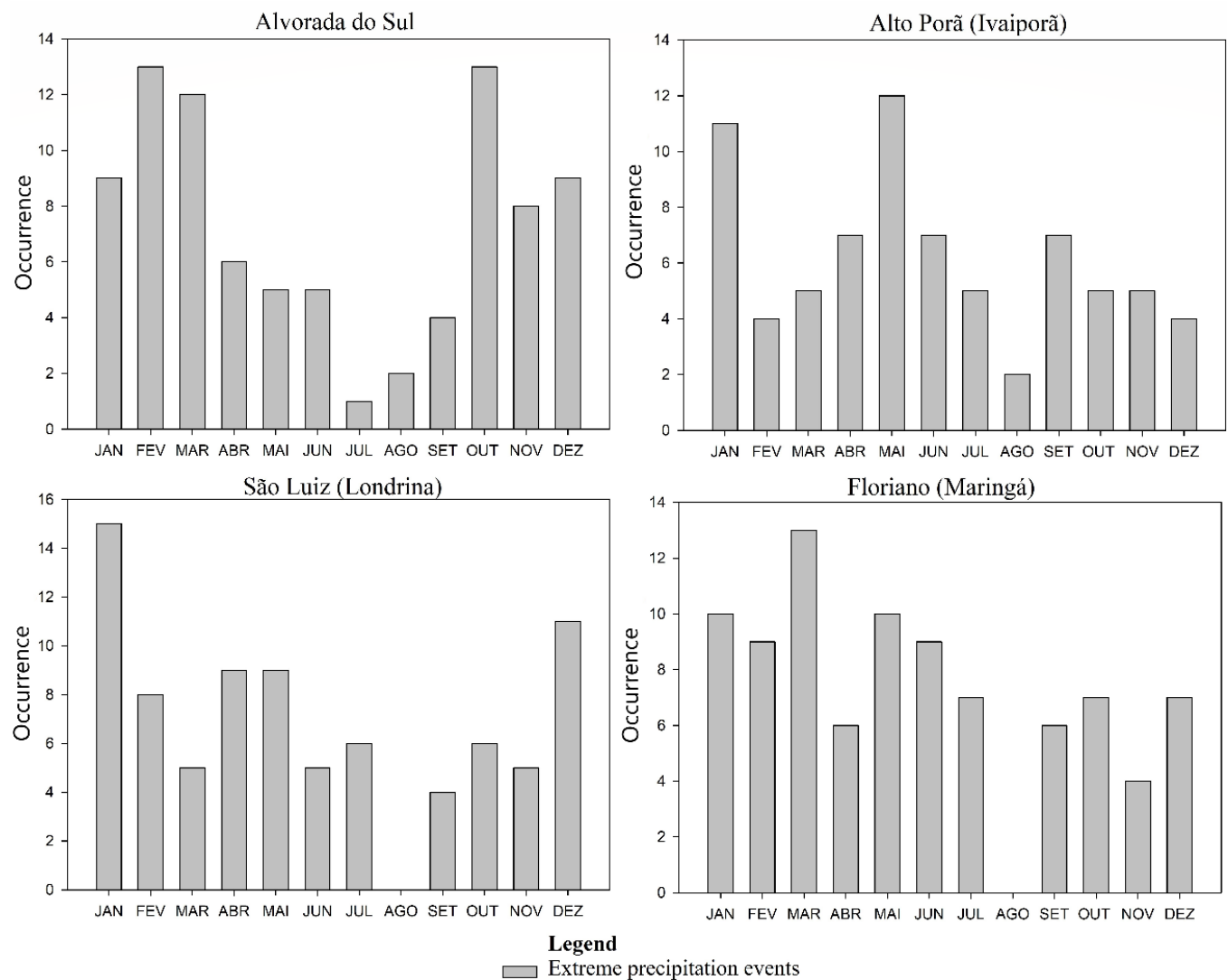

Figure 09 - Occurrence of extreme precipitation events at MNCP. Source: Águas Paraná; ANA; IAPAR e INMET (2019). Authors (2020).

As can be verified, large rainfalls occur in the region and are concentrated in a short period of time. Problems with floods, floods and floods are frequent all over the world, and as mentioned, it is present in at least $80 \%$ of Brazilian cities (MARCELINO, 2007), this figure reaches $90 \%$ in the Iguaçu River Basin, in the South of the Paraná State (CALDANA, et al. 2018). In recent decades, these events have gained greater public attention and investments in infrastructure, concentrated mainly in large cities (CHEN, et al. 2018; HUANG et al. 2018). The planning of this region must always be carried out with measures aimed at improving urban drainage, thus mitigating this type of occurrence, and consequently improving environmental and water quality.

When planning the agricultural calendar, attention should always be paid to the phenological scale of the cultivated species and the climatic information of the region, always aiming to avoid the excessive use of irrigation and agrochemical systems. Since the region has a good distribution of monthly rainfall, however, with expressive variability. 


\section{CONCLUSION}

It was possible to identify that rainfall in the North Central Mesoregion of Paraná is appropriated distributed throughout the year, with significant concentration for the in the Summer and Spring months. However, extreme precipitation and droughts events are noticeable and highly variable, with droughts events occurring mainly in the Fall and Winter months.

The ENSO phenomenon influences the regional distribution and the variability of precipitation in the North Central Mesoregion. This relationship intensifies extreme events, whether drought or rain, and must be taken into account when planning agricultural and urban activities, with most of the extreme precipitation events in the region occurring in El Niño anomalies, and with lower frequency in SST normality.

High rainfall was identified over a 24-hour period in the region. Resilience is a fundamental attribute for the population of MRNCP to adapt and overcome the events caused by these phenomena. They impact and hinder local development, especially for people in vulnerability situations and disregard for public power. Therefore, public incentives must be directed to these episodes in order to prevent urban disasters and social impacts.

\section{REFERENCES}

AGOVINO, M.; CASACCIA, M.; CIOMMI, M.; FERRARA, M.; MARCHESANO, K. Agriculture, climate change and sustainability: The case of EU-28. Ecological Indicators, v. 105, p. 525-543, 2019.

ANDERSON, W.; SEAGER, R.; BAETHGEN, W.; CANE, M. Crop production variability in North and South America forced by life-cycles of the El Niño Southern Oscillation. Agricultural and Forest Meteorology, v. 239, p. 151-165, 2017.

BEREZUK, A. G. Eventos Extremos: Estudo da Chuva de Granizo de 21 de Abril de 2008 na Cidade de Maringá-PR. Revista Brasileira de Climatologia, v. 5, p. 922, 2017.

BERLATO, M. A.; FARENZENA, H.; FONTANA, D. C. Associação entre El Niño Oscilação Sul e a produtividade do milho no Estado do Rio Grande do Sul. Pesquisa Agropecuária Brasileira, v. 40, n. 5, p. 423-432, 2005.

BERLATO, M. A.; FONTANA, D. C. El Niño e a Agricultura da Região Sul do Brasil. Embrapa Trigo. 2011.

BERTILSSON, L.; WIKLUND, K.; TEBALDI, I. M; REZENDE, O. M.; VERÓL, A. P.; \& MIGUEZ, M. G. Urban flood resilience-a multi-criteria index to integrate flood resilience into urban planning. Journal of Hydrology, v. 573, p. 970-982, 2019.

BORSATO, V. A.; MASSOQUIM, N. G.; RODRIGUES, D. U. Os Complexos Convectivos De Mesoescala, as Supercélulas e as Tempestades No Paraná-O Estudo de Caso. Geografia em Questão, v. 12, n. 1. p. 96-212, 2019.

CALDANA, N. F. S.; JUNIOR, G. M. Y.; DE MOURA, D. A. V.; DA COSTA, A. B. F.; CARAMORI, P. H. Ocorrências de Alagamentos, Enxurradas e Inundações e a Variabilidade Pluviométrica na Bacia Hidrográfica do Rio Iguaçu. Revista Brasileira de Climatologia. v. 23, p. 343-355, 2018. 
CALDANA, N. F. S.; MARTELÓCIO, A. C.; RUDKE, A. P.; NITSCHE, P. R.; CARAMORI, P. H. Frequência, Intensidade e Variabilidade Pluviométrica na Mesorregião Sudoeste Paranaense. Revista Brasileira de Climatologia, v. 25, p. 161-181, 2019a.

CALDANA, N. F. S.; RUDKE, A. P.; DA SILVA, I.; NITSCHE, P. R.; CARAMORI, P. $H$. Gênese, Impacto e a Variabilidade das Precipitações de Granizo na Mesorregião Centro-Sul Paranaense, Brasil. Caderno de Geografia, v. 29, p. 6180, 2019b.

CALDANA, N. F. S.; MARTELÓCIO, A. C. Gênese, frequência e intensidade das precipitações de granizo nas Mesorregiões Centro Oriental e Sudeste Paranaense, Brasil. Geotextos, v. 15, p. 205-229, 2019.

CARAMORI, P. H.; CAVIGLIONE, J. H.; WREGE, M. S.; GONÇALVES, S. L.; FARIA, R. D.; ANDROCIOLI FILHO, A.; Sera, T.; CHAVES, J.C.D.; KOGUISHI, M. S. Zoneamento de riscos climáticos para a cultura do café (Coffea arabica L.) no Paraná. Revista Brasileira de Agrometeorologia, v. 9, n. 3, p.486-494, 2001.

CARAMORI, P. H.; CAVIGLIONE, J. H.; WREGE, M. S.; HERTER, F. G.; HAUAGGE, R.; GONÇALVES, S. L.; CITADIN, I.; RICCE, W. D. S. Zoneamento agroclimático para o pessegueiro e a nectarineira no Estado do Paraná. Revista Brasileira de Fruticultura, Jaboticabal, v. 30, n. 4, p. 1040-1044, 2008.

CARAMORI, P. H.; NITSCHE, P. R.; DEPPE, F.; LEITE, E. A.; TSUKAHARA, R. Y.; BORROZZINO, E. Agrometeorologia operacional no estado do Paraná. Agrometeoros, v. 24, p. 65-70, 2016.

CHEN, W.; HUANG, G.; ZHANG, H.; WANG, W. Urban inundation response to rainstorm patterns with a coupled hydrodynamic model: A case study in Haidian Island, China. Journal of Hydrology, v. 564, p. 1022-1035, 2018.

CONTI, J. B. Considerações sobre as mudanças climáticas globais. In: Revista do Departamento de Geografia, v. 16, p.70-75, 2005.

COUTO, F. T.; DUCROCQ, V.; SALGADO, R.; COSTA, M. J. Numerical simulations of significant orographic precipitation in Madeira island. Atmospheric Research, v. 169 , p. $102-112,2016$.

DAFIS, S.; LAGOUVARDOS, K.; KOTRONI, V.; GIANNAROS, T. M.; \& BARTZOKAS, A. Observational and modeling study of a mesoscale convective system during the HyMeX-SOP1. Atmospheric Research, v. 187, p. 1-15, 2017.

DALLACORT, R.; MARTINS, J. A.; INOUE, M. H.; DE FREITAS, P. S. L. ; COLETTI, A. J. Distribuição das chuvas no município de Tangará da Serra, médio norte do Estado de Mato Grosso, Brasil. Acta Scientiarum. Agronomy, v. 33, n. 2, 2011.

ELY, D. F.; DUBREUIL, V. Análise das Tendências espaço-temporais das precipitações anuais para o estado do Paraná - Brasil. Revista Brasileira de Climatologia, v. 21, p. 553-569, 2017.

FERREIRA, L. G. B., DA SILVA CALDANA, N. F., MARTELÓCIO, A. C., DA COSTA, A. B. F., NITSCHE, P. R., \& CARAMORI, P. H. Rainfall Variability and Analysis of Droughts Periods Risks During the Soybean Crop (Glycine max L.) in the Western of Paraná State, Brazil. Revista Brasileira de Climatologia, v. 27, p. 590-611, 2020. 
FIETZ, C. R.; URCHEI, M. A.; FRIZZONE, J. A.; FOLEGATTI, M. V. Probabilidade de ocorrência de períodos secos e chuvosos na região de Dourados, MS. Irriga, v. 3, n. 1, p. 16-22, 1998.

FONTANA, D. C.; BERLATO, M. A. Influência do El Niño Oscilação Sul sobre a precipitação pluvial no estado do Rio Grande do Sul. Revista Brasileira de Agrometeorologia, v. 5, n. 1, p. 127-132, 1997.

HUANG, K.; CHEN, L.; ZHOU, J.; ZHANG, J.; SINGH, V. P. Flood hydrograph coincidence analysis for mainstream and its tributaries. Journal of Hydrology, $\mathrm{v}$. 565, p. 341-353, 2018.

IBGE (Fundação Instituto Brasileiro de Geografia e Estatística), 2019. Censo Demográfico: Brasil, 2017. Rio de Janeiro: IBGE.

IPARDES (Instituto Paranaense de Desenvolvimento Econômico e Social). Leituras regionais: Mesorregião Geográfica Norte Central Paranaense. 2019. Disponível em: http://www.ipardes.gov.br/biblioteca/docs/leituras_reg_meso_norte_central.pdf . Acesso em 02 de fevereiro de 2019.

IPCC. Technical Summary. In: Climate Change 2013: The Physical Science Basis. Contribution of Working Group I to the Fifth Assessment Report of the Intergovernmental Panel on Climate Change. Cambridge University Press, Cambridge, United Kingdom and New York, NY, USA, 2013.

JAMALI, B.; LÖWE, R.; BACH, P. M.; URICH, C.; ARNBJERG-NIELSEN, K.; DELETIC, A. A rapid urban flood inundation and damage assessment model. Journal of Hydrology, v. 564, p. 1085-1098, 2018.

KARIMI, V.; KARAMI, E.; KESHAVARZ, M. Vulnerability and adaptation of livestock producers to climate variability and change. Rangeland Ecology \& Management, v. 71, n. 2, p. 175-184, 2018 a.

KARIMI, V.; KARAMI, E.; KESHAVARZ, M. Climate change and agriculture: Impacts and adaptive responses in Iran. Journal of Integrative Agriculture, $v$. 17 , n. 1 , p. 1-15, 2018b.

LEE, J. T.; KO, K. Y.; LEE, D. I.; YOU, C. H.; LIOU, Y. C. Enhancement of orographic precipitation in Jeju Island during the passage of Typhoon Khanun (2012). Atmospheric Research, v. 201, p. 58-71, 2018.

LEM, S.; ONGHENA, P.; VERSCHAFFEL, L.; VAN DOOREN, W. The heuristic interpretation of box plots. Learning and Instruction, v. 26, p. 22-35, 2013.

LUNGARSKA, A.; CHAKIR, R. Climate induced land use change in France: impacts of agricultural adaptation and climate change mitigation. Ecological Economics, v. 147, p. 134-154. 2018.

MARCELINO, E. V.; Desastres Naturais e Geotecnologias: Conceitos Básicos. INPE, Santa Maria, 2007.

MUELLER, T. G.; PUSULURI, N. B.; MATHIAS, K. K.; CORNELIUS, P. L.; BARNHISEL, R. I.; SHEARER, S. A. Map quality for ordinary kriging and inverse distance weighted interpolation. Soil Science Society of America Journal, v. 68, n. 6, p. 2042-2047, 2004. 
MUSTAFA, A.; BRUWIER, M.; ARCHAMBEAU, P.; ERPICUM, S.; PIROTTON, M.; DEWALS, B.; TELLER, J. Effects of spatial planning on future flood risks in urban environments. Journal of environmental management, v. 225, p. 193-204, 2018.

NITSCHE, P. R., CARAMORI, P. H., RICCE, W. D. S., \&PINTO, L. F. D. Atlas Climático do Estado do Paraná. Londrina, PR: Instituto Agronômico do Paraná IAPAR. 2019. Available in: < http://www.iapar.br/modules/conteudo/conteudo.php?conteudo $=677>$ Acesso em: 12 de outubro de 2019.

NOAA/CPC - National Oceanic and Atmospheric Administration/Climate Prediction Center. Oceanic Niño Index. 2019. Disponível em: http://www.cpc.ncep.noaa.gov/products/analysis_monitoring/ensostuff/ensoyea rs.shtml. Acesso em 14 de junho de 2019.

OLIVEIRA, D. DE; BORROZZINO, E. Risco de geada e ocorrência de horas de frio abaixo de 7 C em Londrina, Guarapuava e Palmas, no estado do Paraná. Agrometeoros, v. 25, n. 2, p. 333-337 2018.

PAILLER, S.; TSANEVA, M. The effects of climate variability on psychological well-being in India. World Development, v. 106, p. 15-26, 2018.

PATHMESWARAN, C.; LOKUPITIYA, E.; WAIDYARATHNE, K. P.; LOKUPITIYA, R. S. Impact of extreme weather events on coconut productivity in three climatic zones of Sri Lanka. European Journal of Agronomy, v. 96, p. 47-53, 2018.

PODESTÁ, G. P.; GLYNN, P. W. The 1997-98 El Nino event in Panama and Galapagos: an update of thermal stress indices relative to coral bleaching. Bulletin of Marine Science, v. 69, n. 1, p. 43-59, 2001.

PUNGE, H. J.; KUNZ, M. Hail observations and hailstorm characteristics in Europe: A review. Atmospheric Research, v. 176, p. 159-184, 2016.

RAO, V. B.; HADA, K. Characteristics of rainfall over Brazil: Annual variations and connections with the Southern Oscillation. Theoretical and Applied Climatology, v. 42, n. 2, p. 81-91, 1990.

ROCHA, P. C.; SANT'ANNA NETO, J. L. Ritmo climático e dinâmica limnológica na planície fluvial do alto rio Paraná, centro-sul do Brasil. Revista Brasileira de Climatologia, v. 6, 2010.

SANCHES, F. O.; VERDUM, R.; FISCH, G. Tendência de longo prazo das chuvas diárias no Sudoeste do Rio Grande do Sul: os eventos extremos e a arenização. Revista Brasileira de Geografia Física, v. 7, p. 1100-1109, n. 2014.

SANCHEZ, J. L.; MERINO, A.; MELCÓN, P.; GARCÍA-ORTEGA, E.; FERNÁNDEZGONZÁLEZ, S.; BERTHET, C.; DESSENS, J. Are meteorological conditions favoring hail precipitation change in Southern Europe? Analysis of the period 1948-2015. Atmospheric Research, v. 198, p. 1-10, 2017.

SANTI, A.; VICARI, M. B.; PANDOLFO, C.; DALMAGO, G. A.; MASSIGNAM, A. M. ; PASINATO, A. Impacto de cenários futuros de clima no zoneamento agroclimático do trigo na região Sul do Brasil. Agrometeoros, v. 25, n. 2, p. 303$311,2018$. 
SCAGLIONI, T. P.; SARAIVA, J. M. B. Climatologia dos sistemas precipitantes para o período de fevereiro a dezembro de 2003, no Rio Grande do Sul. In: Congresso Brasileiro De Meteorologia. 2004.

SCHNEIDER, H.; DA SILVA, C. A. O uso do modelo box plot na identificação de anos-padrão secos, chuvosos e habituais na microrregião de Dourados, Mato Grosso do Sul. Revista do Departamento de Geografia, v. 27, p. 131-146, 2014.

SILVA, M. E. S.; SILVA, C. B. Variabilidade Climática - processos físicos e dinâmicos nos oceanos e atmosfera. Revista do Departamento de Geografia, v. 30, p. 372-406, 2012.

SILVESTRE, M. R.; SANT'ANNA NETO, J. L.; FLORES, E. F. Critérios estatísticos para definir anos padrão: uma contribuição à climatologia geográfica. Revista Formação, v. 2, n. 20, p. 23-53, 2013.

SOMBOONSUKE, B.; PHITTHAYAPHINANT, P.; SDOODEE, S.; KONGMANEE, C. Farmers' perceptions of impacts of climate variability on agriculture and adaptation strategies in Songkhla. Kasetsart Journal of Social Sciences, v. 39, n. 2, p. 277-283, 2018.

DE SOUSA, J. W.; DE OLIVEIRA, P. F. Risco climático para o café Conilon (Coffea canephora) nos municípios de Rio Branco, Tarauacá e Cruzeiro do Sul, AC. Revista Brasileira de Ciências da Amazônia, v. 7, n. 2, p. 31-40, 2018.

DE SOUZA, D. C. F.; DA SILVA LIMA, I.; SANTOS, J. A. S.; DE ALMEIDA, A. Q.; GONZAGA, M. I. S.; LIMA, J. F. Zoneamento Agroclimático da Palma Forrageira (Opuntia Sp) Para o Estado de Sergipe. Revista Brasileira de Agricultura Irrigada, v. 12, n. 1, p. 2338, 2018.

TAYT'SOHN, F. C. O. Assessing sugarcane expansion to ethanol production under climate change scenarios in Paranaíba river basin-Brazil. Biomass and Bioenergy, v. 119, p. 436-445, 2018.

TREFALT, S.; MARTYNOV, A.; BARRAS, H.; BESIC, N.; HERING, A. M.; LENGGENHAGER, S.; NOTI, P; RÖTHLISBERGER, M; SCHEMM, S; GERMANN, U.; MARTIUS, O. A Severe Hail Storm in Complex Topography in SwitzerlandObservations and Processes. Atmospheric Research, v. 209, p. 76-94, 2018.

TRENBERTH, K.; NATIONAL CENTER FOR ATMOSPHERIC RESEARCH STAFF (Eds). Última alteração em 02 fev 2016. "The Climate Data Guide: Niño SST Indices (Niño 1+2, 3, 3.4, 4; ONI and TNI)". Disponível em: https://climatedataguide.ucar.edu/climate-data/Niño-sst-indices-Niño-12-3-344-oni-and-tni. Acesso em 22 de maio de $2019>$.

WIRÉHN, L. Nordic agriculture under climate change: A systematic review of challenges, opportunities and adaptation strategies for crop production. Land Use Policy, v. 77, p. 63-74. 2018 